\title{
Raziskovanje glasbenega razvoja in pomen glasbenega okolja za dojenčka
}

\author{
Bogdana Borota \\ Univerza na Primorskem \\ bogdana.borota@pef.upr.si
}

Raziskovanje glasbenega razvoja pri dojenčku je poseben izziv, ki so se ga v 20. stoletju lotevali na različne načine. Pogled na pristope k raziskovanju z diahrone perspektive nam pokaže pomemben premik od opazovanja lastnih otrok in testiranja $v$ laboratorijih $\mathrm{k}$ opazovanju glasbenega vedênja $v$ naravnem okolju. Pod vplivom drugih znanosti so se raznovrstni odzivi dojenčka na glasbo interpretirali kot oblike glasbenega vedênja, in ne kot odziv na stimulus iz okolja. S poznavanjem prirojenih glasbenih dispozicij se je védenje o oblikah glasbenega vedênja spremenilo. V prispevku zato zagovarjamo predpostavko, da je dojenček velik poznavalec glasbe. Pri tem poudarimo pomen procesov akulturacije $v$ družinskem okolju in na novo opredelimo nekatere oblike glasbenega vedênja dojenčka v povezavi z njegovimi zaznavnimi sposobnostmi ter razvojem glasbene zavesti. Na podlagi raziskav $v$ ameriškem kulturnem okolju ugotavljamo tudi, da v prvem letu življenja odzivov dojenčka na glasbo in zvoke še ne moremo interpretirati kot oblike melodičnega ali ritmičnega vedênja niti jih ne moremo povezovati s sposobnostjo imitacije glasbe.

Ključne besede: raziskovanje glasbenega razvoja, glasbeni razvoj dojenčka, glasbene dispozicije, oblike glasbene zavesti pri dojenčku

\section{Uvod}

Tako kot ni otroka brez vsaj nekaj inteligentnosti, ga tudi ni brez vsaj nekaj glasbenih dispozicij (Gordon 1995). ${ }^{1}$ Edwin Gordon s to ugotovitvijo usmeri našo pozornost na iskanje povezav med glasbenim okoljem in razvojem glasbenih dispozicij. Prirojene dispozicije za glasbo so podobne kot za govor. $\checkmark$ obeh primerih gre za slušno-govorno modaliteto, saj jezik in glasbo zaznavamo in izvajamo kot zaporedje govorjenih, zapetih ali preko gibanja v času izvedenih zvočnih vzorcev (Sloboda 2007). Ameriški psiholog in raziskovalec glasbene kognicije John Sloboda je glasbene dispozicije opredelil na

\footnotetext{
${ }^{1}$ Gordonove raziskave nakazujejo, da ima posameznik najvišjo stopnjo glasbenega potenciala ob rojstvu. Če otroka ne spodbujamo, da glasbene dispozicije uporablja, se v možganih ne tvorijo sinapse. Nevrolog Robert Post ugotavlja, da sinapse, ki niso uporabljene za glasbo, začnejo podpirati druge zaznave, kot je npr. vidna (Gordon 1995).
} 
naslednjih področjih: reagiranje na zvok in ugotavljanje smeri zvoka, razlikovanje med glasbenimi in neglasbenimi zvoki, glasbeno čebljanje, težnja po usklajevanju gibanja z glasbo in pomnjenje glasbenih vzorcev (Sloboda 2007). Prirojenih dispozicij ne smemo zamenjevati z dednostjo. Ni dokazov, da bi otrok talentiranih glasbenikov podedoval tudi glasbene sposobnosti (Motte-Haber 1990; Gordon 1995). Učitelj tako mora biti pozoren na individualne potrebe in glasbeni potencial vsakega otroka posebej.

$Z$ učenjem $v$ spodbudnem okolju in lastno aktivnostjo dispozicije razvijemo $v$ glasbene sposobnosti. ${ }^{2}$ Sposobnosti lahko izrazimo, če imamo razvite spretnosti. ${ }^{3}$ Pri tem vemo, da otrokove sposobnosti prehitevajo motorično izvedbo. Otrok v glasbi veliko več zazna, doživi, si zapomni in razume, kot lahko izrazi (Motte-Haber 1990). Tudi tu najdemo vzporednice z govornim razvojem. Otrok razume pomen povedi, ki je oblikovana po določenih pravilih sintakse, še preden jo zna po teh pravilih tvoriti. Tudi v glasbi otrok zazna glasbeno celoto in se odzove nanjo, še preden zna po pravilih glasbene sintakse ustvariti novo (Sloboda 2007). Razliko med glasbenimi sposobnostmi in dosežki otroka ugotavlja tudi Gordon (1995) in dodaja, da povezave med njimi niso vedno premo sorazmerne. Raven glasbenih sposobnosti se vse do 9. leta starosti spreminja $v$ odvisnosti od kakovosti glasbenega okolja, v katerem otrok živi. Po tem obdobju se otrokov glasbeni potencial ustali in okolje nima več vpliva na raven razvitosti glasbenih sposobnosti (Gordon 1995).

Otrok nosi v sebi ustvarjalne potenciale. Nestrpno čaka na priložnosti, da jih bo izrazil in da ga bomo mi, odrasli, opazili (Rinaldi 2006). Če njegovim glasbenim dosežkom pozorno prisluhnemo, zagledamo podobo »velikega glasbenika« in poznavalca glasbe. Izgrajevanje te podobe je odvisno od našega védenja o otroku in naših pričakovanj, ki jih gojimo do njega (Borota 2009).

V prispevku želimo razpravljati o glasbenem razvoju otroka. Posebno pozornost namenjamo dojenčku - otroku v prvem letu življenja. Pogled na nje-

\footnotetext{
${ }^{2}$ Izraz se najpogosteje uporablja za elementarne glasbene sposobnosti, ki se razvijejo iz glasbenih dispozicij. To so melodične in ritmične sposobnosti pa tudi sposobnost harmonskega občutenja, ki se razvije na podlagi melodičnih sposobnosti. V preteklosti smo te sposobnosti poimenovali z izrazom posluh (melodični, ritmični, harmonski posluh) (Oblak 2001). Elementarne glasbene sposobnosti so odvisne od sposobnosti za posploševanje, ki otroku omogoča npr. nadaljevati začeto glasbeno misel, odgovoriti na glasbeno vprašanje, predvideti potek melodije (Gordon 1995).

${ }^{3}$ Pri glasbi gre za spretnost rabe dveh temeljnih izraznih sredstev: (pevskega) glasu in rokovanja z glasbili (Borota 2013). Omenja se tudi spretnost poslušanja glasbe, predvsem na področju preusmerjanja pozornosti med elementi in izraznimi sredstvi glasbe, kot so motivi in oblikovni deli, ritem, melodija, zvočna barva, tempo ... (Bamberger 2000).
} 
gove zmožnosti se je skozi čas spreminjal. $V$ ta namen bomo raziskovanje glasbenega razvoja in védenje o glasbenih sposobnosti pri otroku osvetlili skozi diahrono perspektivo. Predpostavljamo, da je dojenček velik poznavalec glasbe. Pri utemeljevanju predpostavke se opiramo na teorije razvoja glasbenih sposobnosti, ki izpostavljajo pomen kritičnih razvojnih obdobij za glasbo in bogatega glasbenega okolja v socialno-kulturnem kontekstu. Ugotovitve so lahko $v$ pomoč pri razumevanju pomena procesov inkulturalizacije in posebnosti zgodnjega glasbenega razvoja pa tudi razumevanja otrokovega doživljanja in izražanja doživetij.

\section{Pogled na raziskovanje in razumevanje glasbenega razvoja z diahrone perspektive}

Začetki znanstvenega preučevanja glasbenega razvoja segajo $v$ začetek 20. stoletja. Raziskovalci so z opazovanjem lastnih otrok prepoznavali in opisovali značilna glasbena vedênja $v$ povezavi z glasbenim spominom ter sposobnosti prepoznavanja melodičnih in ritmičnih prvin (Motte-Haber 1990). Po zgledu razvojne psihologije so bila raziskovanja usmerjena $v$ opredeljevanje glasbenih razvojnih stopenj in iskanje praoblik glasbenega izražanja. Iz tega obdobja je znana raziskava nemškega psihologa Heinza Wernerja (1890-1964). ${ }^{4}$ Menil je, da je odkril ontogenetično melodično praobliko. Praoblika otrokovih pevskih začetkov naj bi bil ton, ki pada v glissandu, ki ga triletni otrok že more razločiti kot motiv male terce (str. 326). Mala terca naj bi bila tako izhodišče za otroške pesmi in glasbeno opismenjevanje otrok. Tej raziskavi je bilo očitano, da je bila zanemarjena predpostavka, da je lahko mala terca $v$ določenem glasbenem okolju priučljiva.

Vrsto let so strokovnjaki iskali odgovor na vprašanje, ali obstaja enovita glasbena sposobnost ali gre za raznovrstne glasbene sposobnosti, ki delujejo navzven usklajeno in vzajemno (Radoš 2010). Tovrstno raziskovanje se je osredinilo predvsem na populacijo otrok $v$ srednjem in poznem otroštvu ${ }^{5}$ ter mladostnike. Pogosto je šlo za primerjavo glasbenih sposobnosti otrok, ki niso ali so bili deležni glasbenega izobraževanja.

Prvi psihološki test glasbenih sposobnosti je leta 1880 razvil Carl Stumpf (1848-1936). Meril je reprodukcijo tona, izvedenega na klavirju, sposobnost razlikovanja tonskih višin in oceno stopnje konsonance (Radoš 2010). Prvi

\footnotetext{
${ }^{4} \mathrm{~V}$ raziskavi je sodelovalo 45 otrok iz družin nižjega ekomskega statusa na Dunaju. Raziskovalec je bil mnenja, da je tako izločil vpliv okolja in možnosti vpliva glasbenega šolanja, saj otroci iz revnih družin niso deležni glasbenega šolanja (Motte-Haber 1990).

${ }^{5}$ Otroci, stari med 6 in 11 let.
} 
standardizirani test, zasnovan na teoretičnih osnovah, je razvil Carl Emil Seashore (1866-1949). Bil je zagovornik eksaktnega merjenja in natančne analize dobljenih podatkov.

Zanimivo je, da so raziskovanje glasbenega razvoja vse do 80 . let 20. stoletja izvajali psihologi. Ni naključje, da gre za obdobje intenzivnega razvoja testnih baterij in drugih inštrumentov za merjenje glasbenih sposobnosti. Raziskave so potekale v laboratorijih. Zvok in glasba sta bila izvedena na generatorjih. Merski inštrumenti so bili zasnovani na tedanjih teorijah glasbenega razvoja. Unitaristična smer teorije glasbenih sposobnosti je zagovarjala enovito glasbeno sposobnost, ki so jo pogosto poimenovali kot muzikaličnost. Zagovorniki te teorije so bili predvsem angleški raziskovalci. Očitalo se jim je, da so pri testiranju merili posamezne komponente muzikalnosti, na koncu pa rezultate preprosto sešteli (Rojko 2010). Druga smer je atomistična. Zagovarja stališče, da je muzikaličnost skupek raznovrstnih glasbenih sposobnosti. To smer so razvijali ameriški psihologi.

Glavni zagovornik enovite glasbene sposobnosti je angleški psiholog Henry Wing. ${ }^{6} \mathrm{Z}$ raziskavami in faktorsko analizo je izluščil splošni faktor glasbenih sposobnosti. Glasbeno inteligentnost je opredelil kot splošno sposobnost zaznavanja in vrednotenja glasbe, ki se navzven kaže kot sposobnost percepcije, recepcije in produkcije glasbe ter sposobnost estetske presoje glasbe (Radoš 2010, 100). Skupaj z Arnoldom Bentleyjem (1913-2001) sta, pod vplivom teorije o splošnem inteligenčnem količniku, računala količnik muzikalnosti.

Danes je teorija o inteligenčnem količniku Charlesa Spearmana presežena. Gordon je mnenja, da je povezav med glasbenimi sposobnostmi in testi inteligentnosti le za od 5 do 10 odstotkov (Gordon 1967). Bentley se je kasneje od ekstremističnih pogledov na razvoj glasbenih sposobnosti oddaljil. $\mathrm{Na}$ predpostavkah o obstoju treh elementarnih glasbenih sposobnosti ${ }^{7}$ je razvil enega najbolj znanih testov, mere glasbenih sposobnosti (angl. Measures of Musical Ability) (Smolej-Fritz 200o). Test je bil uporabljen v raziskavi Bar-

\footnotetext{
${ }^{6}$ Pred njim je bil poznan raziskovalec enovite glasbene sposobnosti madžarski psiholog Geza Révész, ki je imel za takratne razmere ogromen lasten laboratorij $s$ kar 40 sobami za testiranje glasbenih sposobnosti (Radoš 2010). Štejemo ga za pionirja eksperimentalnega ugotavljanja muzikalnosti pri otrocih (Rojko 1981). Opredelil je osem slušno-glasbenih sposobnosti: smisel za ritem, regionalni sluh, analizo dvoglasja in večglasja, relativni posluh, smisel za harmonijo, glasbeno dojemanje in ponavljanje melodije ter igranje po posluhu z improvizacijo (Révész 2001).

${ }^{7}$ Te so: sposobnost razlikovanja tonskih višin, sposobnost pomnjenja melodije in sposobnost pomnjenja ritma, ki se jim doda sposobnost analize akordov (Radoš 2010).
} 
bare Smolej-Fritz na populaciji otrok v Sloveniji med 7. in 14. letom starosti, na vzorcu 436 otrok. Namen raziskave je bil ugotoviti razvoj sposobnosti razlikovanja višin, pomnjenja melodije, pomnjenja ritma in analize sozvočij glede na obiskovanje ali neobiskovanje glasbene šole. Rezultati so pokazali, da se pri učencih, ki obiskujejo glasbeno šolo, omenjene sposobnosti razvijejo prej. Pri otrocih, ki obiskujejo glasbeno šolo, in pri tistih, ki je ne obiskujejo, povprečni dosežki postopno naraščajo s starostjo do približno 12. leta in pol. Kaže, da se razvoj te sposobnosti zaključuje nekje okoli te starosti pri obeh skupinah otrok, s tem da pri otrocih, ki obiskujejo glasbeno šolo, na višjem nivoju kot pri otrocih, ki glasbene šole ne obiskujejo (Smolej-Fritz 2000, 103).

Eden vidnejših predstavnikov atomistične smeri teorije glasbenih sposobnosti je Carl Emil Seashore (1866-1949). Muzikalnost je opredelil kot skupek glasbenih sposobnosti, ki se združujejo v glasbeno zavest (Seashore 1969; Radoš 2010). Zagovarja stališče, da muzikalnost ni enostaven seštevek posameznih sposobnosti, ampak je integrirana celota, ki jo bolje spoznamo, če raziščemo posamezne komponente. Baterija testov, ki jo je razvil posebej za glasbene amaterje in za glasbeno izobražene, vključuje teste za tonsko višino, jakost, ritem, tonska trajanja, zvočno barvo, konsonanco in glasbeni spomin (Rojko 1981; Radoš 2010). Zanimivo je, da je pozornost usmeril na senzorne sposobnosti. Pri tem je izhajal iz predpostavke, da je zvok osrednji medij za glasbo. Njegove fizikalne lastnosti zaznavamo in spoznavamo preko čutil (Seashore 1969).

Obdobje testiranj $\vee$ glasbi je zaokrožil ameriški psiholog Edwin Gordon (1927-2015), ki je teste osnovne mere glasbene avdiacije (angl. The Primary Measures of Music Audiation) prilagodil tudi za mlajše otroke, stare od pet let in pol do osem let. S testi merimo melodične in ritmične sposobnosti glede na razlikovanje enakih in različnih glasbenih motivov (Gordon 1986). Vsak test vsebuje 40 nalog. Teste je za populacijo slovenskih otrok prilagodila Barbara Sicherl-Kafol, tako, da je upoštevala značilno motiviko slovenske glasbe. Zmanjšala je tudi število nalog na devet za vsak preizkus. V eksperimentalni raziskavi o učinkih celostne glasbene vzgoje na uravnotežen razvoj otroka na afektivno-socialnem, psihomotoričnem in kognitivnem področju je merila sposobnosti ritmične in melodične avdiacije otrok $v$ prvem razredu osemletke. Otroci, ki so bili deležni celostne glasbene vzgoje, so dosegli višje rezultate na področjih melodične in ritmične avdiacije kot otroci kontrolne skupine, ki so imeli klasičen pouk glasbene vzgoje (Sicherl-Kafol 2001).

Edwin Gordon je glasbeni razvoj raziskoval v povezavi z avdiacijo. Opredeljuje jo kot sposobnost predvidevanja glasbenih dogodkov brez predhodne 
fizične prezentacije zvoka. ${ }^{8}$ Pravi, da je avdiacija za glasbo to, kar je mišljenje za jezik. Je osnova glasbenim sposobnostim in dosežkom. Povezuje jo s »čistim « zvokom, in ne s sposobnostmi branja ter pisanja glasbe (Gordon 1967; 1984; 1995). Avdiacijo lahko razvijamo za vse glasbene parametre, kot so zvočna barva, ritem, melodija, dinamika, artikulacija, agogika, metrum in tempo (Gordon 1997).

Ker je avdiacija pogojena z glasbenim spominom, se je polje raziskovanja razširilo na glasbeno kognicijo in načine »skladiščenja " glasbenih informacij. Raziskovanje se je iz laboratorijev preselilo v naravno okolje. Osrednja tehnika raziskovanja niso testi, pač pa opazovanje z udeležbo ali brez nje v problemsko zasnovanih situacijah. Predmet raziskav so glasbeno vedênje, procesi učenja in ustvarjanja ter glasbeni dosežki otrok. Pomembna predstavnica te generacije raziskovalcev je glasbenica in razvojna psihologinja Jeanne Bamberger (1925-). Sprva se je naslanjala na teorijo konstruktivizma. Glasbeni razvoj je želela razčleniti po etapah logičnega mišljenja, kot jih je opredelil Jeanne Piaget. Ugotovila je, da ima glasbeno mišljenje svoja pravila in omejitve in zato ga ni mogoče vključiti v jezikovno ali logično-matematično mišljenje. Glasbeno mišljenje tudi nima enovitega razvoja. $V$ fazi figuralnega mišljenja, ki je značilna za otroka v zgodnjem obdobju, imata pomembno vlogo glasbena intuicija in sposobnost predvidevanja glasbenih dogodkov. Ta vrsta mišljenja se pod vplivom učenja nadgradi $v$ formalni način mišljenja, ki je podprt z znanjem o glasbi kot simbolnem sistemu (Gardner 1995; Bamberger 2000). Tu najdemo stičišče s teorijo simbolnih sistemov Howarda Gardnerja, po kateri glasbeno inteligentnost opredeli kot eno od sedmih samostojnih inteligentnosti (Gardner 1995). Pripisuje ji lasten simbolni sistem, $v$ katerem poteka glasbena komunikacija. Razumemo jo kot zmožnost posameznika za glasbeno percepcijo, recepcijo in produkcijo. Nas zanimajo prve oblike te glasbene zavesti in glasbenega vedênja pri dojenčku. Pri tem se bomo oprli na ugotovitve danes delujočih raziskovalcev, kot so Hanuš in Mechthild Papoušek, Sandra E. Trebuh, E. Glenn Schellenberg in John Sloboda.

\section{Dojenček je dober poznavalec glasbe}

Pogosto citirani stavek, da se med vsemi nadarjenostmi, s katerimi je obdarjen človek, najprej pokaže glasbena (Gardner 1995, 135), je primerno izhodišče za predpostavko, da je dojenček velik poznavalec glasbe. Poznavalca v tem kontekstu razumemo kot pozornega poslušalca, ki ima velike zaznavne

\footnotetext{
${ }^{8}$ Audiacije ne smemo zamenjevati s slušno zaznavo, notranjim slišanjem, imitacijo, glasbenim spominom ali slušnim razlikovanjem (Gordon 1995).
} 
sposobnosti in zna razlikovati glasbene izvedbe. Ta sposobnost zahteva poznavanje glasbe določenega kulturnega okolja. Tovrstno znanje ni dano neizkušenim poslušalcem. Sprašujemo se, kako lahko to sposobnost pripisujemo dojenčku. Mnenje ugledne ameriške raziskovalke zgodnjega glasbenega razvoja Sandre E. Trebuh je, da je to povezano z njegovimi glasbenimi dispozicijami, odličnim spominom za glasbo, bogatim glasbenim okoljem, radovednostjo in velikim zanimanjem za ekspresivno glasbo (Trebuh 2006).

Razvojni psihologi ugotavljajo, da ima dojenček v primerjavi z zelo omejeno gibalno kompetentnostjo izjemno dobro razvite vse temeljne čute, ki, z izjemo vida, dosežejo primerljivo učinkovitost s čuti odraslega že v prvih nekaj mesecih po rojstvu (Zupančič 2004, 186). Dojenček se uči in spoznava svet s čutili. Čutila so primarni vzvodi tudi za občutenja. Pri otroku jih razvijamo na treh ravneh: (1) na ravni senzornega stika s stvarmi in z dogodki (veččutno učenje); (2) razpoznavanja lastnega razpoloženja in občutenja na telesu (mišična napetost, neudobje, ugodje, čustva); (3) občutenj, ki gredo preko realnosti, v območje domišljije, ki vključuje tudi sanje, spomine in predvidevanja (Mayesky 2009).

Prvo obsežno presečno študijo je leta 1976 opravil nemški filozof in pedagog Helmut Moog na vzorcu 500 otrok, starih od treh mesecev do petih let. $\mathrm{Na}$ magnetofonske trakove je posnel šest testov. ${ }^{9}$ Natančno je opazoval in popisoval kakršnekoli odzive otrok na predvajane zvočne posnetke. Ugotovil je, da 6-mesečni dojenčki prenehajo z dejavnostjo (tudi s hranjenjem) in se obrnejo proti izvoru zvoka z izrazi začudenja. Prepoznal je njihovo selekcionirano pozornost v povezavi s kakovostjo zvoka. Pozornost dojenčka v večji meri pritegnejo glasbeni vzorci kot neglasbeni. Ta opažanja označi kot preferenco dojenčka do čutno lepega zvoka (angl. sensuously beautiful sound) (Moog 1976 v Sloboda 2007).

John Sloboda je kritičen do raziskovalnih pristopov, ki temeljijo na subjektivnih ocenah opazovalca o odzivanju dojenčka na glasbene stimuluse. Stališče utemelji na ugotovitvah razvojne psihologije. Znano je, da se dojenček odziva na spremembe v okolju (Zupančič 2004). Glasbeni dražljaj je lahko le ena od teh sprememb. Zato osredotočenosti dojenčka na zvok ali njegove odzive na glasbene dražljaje še ne moremo razumeti kot obliko glasbenega

\footnotetext{
${ }^{9}$ 1. test je vseboval posnetke treh otroških pesmi, ki so jih zapeli otroci, 2 . test je bil posnetek ritmičnega izrekanja besednih zvez, 3. test je vseboval ritmične vzorce, zaigrane na različna rimtična glasbila, 4 . test so bili posnetki instrumentalne glasbe, 5 . test je vseboval tonalni motiv glasbe iz 4. testa, ki mu je dodal različne disonantne harmonije, 6 . test je bil sestavljen iz neglasbenih zvokov, kot sta zvok sesalca, prometa...
} 
vedênja (Sloboda 2007). ${ }^{10}$ Ključna pri tem je glasbena zavest, ki se kaže v zmožnosti diferenciacije tonskih višin, značilnih samo za glasbene zvoke (Sloboda 2007, 198).

Nadaljnja raziskovanja zgodnjega glasbenega razvoja so zato temeljila na novih tehnikah opazovanja, ki so zmanjševale potencialno subjektivnost opazovalca. Kot primer učinkovitega pristopa se je uveljavilo opazovanje dojenčka med gledanjem lutkovne predstave $v$ živo, $v$ kateri v ozadju potekajo ponavljajoči se glasbeni vzorci, sestavljeni z od 5 do 10 toni. Dojenček med gledanjem predstave reagira na majhne, subtilne spremembe $v$ glasbi. Melodične ali ritmične spremembe navadno povzročijo, da se obrne proti zvočniku, kot da bi preverjal razlog za spremembo. Obrat, ki sledi takoj po predvajani spremembi, se za nekaj sekund nagradi z izbranim vizualnim prikazom, primernim starosti otroka. Obračanje pozornosti izven navedenega konteksta se ne nagrajuje. Dojenček med šestim in desetim mesecem se teh pravil nauči v nekaj minutah. Na tej osnovi raziskovalci ugotavljajo odzive dojenčka na spremembe $v$ glasbenih vzorcih (Trebuh 2006).

Prelomnico v razumevanju glasbenega razvoja dojenčka pomeni raziskava Hsing-Wu Changa in Sandre E. Trebuh (1977a), ki sta pri 5-mesečnih dojenčkih ugotavljala zmožnost zaznavanja razmerij med tonskimi višinami v glasbenem vzorcu. Pri tem sta se naslonila na paradigmo habituacije ${ }^{11}$ in merjenja srčnega utripa. Dojenček je poslušal ponavljanje 6-tonskega atonalnega glasbenega vzorca. Ko se je navadil na prvi glasbeni vzorec, so mu predvajali drugega. Drugi vzorec se je začel ali na enaki tonski višini s spremenjenimi tonskimi razmerji v nadaljevanju ali pa je bil izveden kot transpozicija prvega. Opazili so, da se je srčni utrip dojenčka spremenil pri spremembah razmerij med toni (nova melodija), ne pa tudi pri transpozicijah. Prav tako sta ugotovila, da je dojenček občutljiv na ritmične spremembe v zaporedno predvajanih ritmičnih vzorcih (Chang in Trebuh 1977b). Zanimiva je tudi ugotovitev, da dojenčki te subtilne razlike $v$ melodičnih in ritmičnih vzorcih zaznavajo $\checkmark$ glasbi ne glede na to, ali izvira iz njihovega kulturnega okolja ali od drugod (Trebuh in Hannon 2006). Sposobnost zaznave dojenčka za odzivanje na spremembe $v$ tonskih in ritmičnih razmerjih $v$ zaporednih zvočnih vzorcih Sloboda označuje kot prvo obliko glasbenega vedênja (Sloboda 2007). Ti principi so $v$ obdobju zgodnjega glasbenega razvoja univerzalni glede na

\footnotetext{
${ }^{10}$ Nakazuje se potreba po redefiniranju glasbenih mejnikov, kot sta jih prvič objavila Rosamund Shuter-Dyson in Clive Gabriel v knjigi The Psychology of Musical Ability (1981). Prvi mejnik v glasbenem razvoju opišeta kot odziv dojenčka na zvok (Hargreaves 2001, 61).

${ }^{11}$ Do habituacije pride pri ponavljanju istega stimulusa. Ko se dojenček na stimulus privadi, se mu srčni utrip umiri in ustali.
} 
starost in spol, zato se sklepa, da temeljijo na bioloških predispozicijah (Deliège in Sloboda 1996).

Odziv dojenčka na glasbo je običajno gibalni. Helmut Moog je v svoji raziskavi opazil, da se dojenčki, ki so med poslušanjem sedeli, zibajo levo-desno, tisti, ki so stali, pa so klecali v kolenih gor-dol. Enake gibalne odzive je opazil pri poslušanju petja ali instrumentalne glasbe. Sloboda ugotavlja, da v prvem letu starosti teh gibalnih odzivov še ne moremo razumeti kot ritmično vedênje, čeprav pri dojenčku opazimo še druge z ritmom povezane aktivnosti, kot sta enakomerno ponavljanje zloga ali besede ter enakomerno udarjanje $\mathrm{s}$ predmetom ob podlago (Deliège in Sloboda 1996). Da lahko neko vedenje opredelimo kot ritmično, je treba $v$ gibalnih odzivih prepoznati naslednje: podelitev glasbenega utripa ${ }^{12}$ vsaj $v$ zaporedju dveh ali več glasbenih utripov; ohranjanje glasbenega utripa med pavzo in nadaljevanje $z$ njim po pavzi; posnemanje ritmičnih motivov ter gibanje v ritmu glasbe ali izvajanje metruma (Deliège in Sloboda 1996). Nobena od navedenih oblik glasbenega vedênja se ne pojavi pred prvim letom (Sloboda 2007).

Z rezultati temeljnih raziskav lahko potrdimo predpostavko, da je dojenček poznavalec glasbe. Raven razvitosti glasbene zavesti prepoznavamo z njegovim odzivom na spremembe $v$ melodični in ritmični strukturi ponavljajočih se glasbenih vzorcev. Slednje strokovnjaki opredeljujejo kot prvo obliko glasbene zavesti. Opredelimo jo lahko kot mejnik v glasbenem razvoju. Ključni dejavniki pri doseganju tega mejnika so interakcije $v$ glasbenem okolju in $z$ njim povezani procesi akulturacije.

\section{Pomen akulturacije v domačem okolju za glasbeni razvoj dojenčka}

Akulturacija (angl. enculturation) je del procesov socializacije, ki potekajo v interakciji z okoljem. Gre za sprejemanje, učenje in usklajevanje posameznika $s$ kulturo okolja. $V$ tem prispevku jo obravnavamo $v$ povezavi z interakcijami $v$ družinskem okolju, v katerem se otrok privaja na glasbo in glasbene navade. Povezava med družinskim okoljem in glasbenim razvojem dolgo časa ni pritegnilo pozornosti raziskovalcev (Papoušek 1996). Raziskave o pomenu akulturacije za govorni in glasbeni razvoj dojenčka so bile narejene konec 20. stoletja. V ameriškem kulturnem okolju so preučevali značilnosti govorne in glasbene komunikacije matere $z$ dojenčkom. Ugotovili so, da se govor, ki je usmerjen na dojenčka, razlikuje od običajnega govora po višini glasovne

${ }^{12} \mathrm{Z}$ izrazom poimenujemo splošno občutenje glasbenega časa, ki ga odrasli navzven spontano izražamo s tleskanjem, z zibanjem, udarjanjem z nogo ob tla, ki je usklajeno z glasbenim potekom. 
lege, podaljševanju samoglasnikov, ponavljajočih se besednih zvezah in modulaciji glasu (Papoušek, Papoušek in Symmes 1991). Opažene modulacije in konture glasu v kontekstu nasprotnih si situacij, kot sta vznemirjenost - pomirjenost, odobravanje - neodobravanje, predstavljajo univerzalno predverbalno komunikacijo matere $z$ dojenčkom ne glede na kulturno okolje (Papoušek, Papoušek in Symmes 1991). Komunikacija, v kateri ima mati priložnost za izražanje lastnih čustev do otroka, ima tudi močen doživljajski naboj (Schubert in McPherson 2006).

Vsa kulturna okolja poznajo glasbo, ki jo mati izvaja med negovanjem dojenčka ali drugimi vsakodnevnimi opravili (Trebuh in Trainor 1998). Strokovnjaki ugotavljajo, da večina dojenčkov prvo glasbeno izkušnjo $v$ živo doživi ob materinem petju ali petju skrbnika. Na populaciji ameriških mater je bilo ugotovljeno, da severnoameriške matere, usmerjene $\mathrm{k}$ sodobnejšemu življenjskemu slogu, pojejo živahne pesmi, ob katerih se gibajo in igrajo. Matere iz tradicionalnejših okolij pa pojejo uspavanke (Trebuh, Hill in Kamenetsky 1997). Matere s sodobnejšim življenjskim slogom izvajajo glasbo z namenom spodbujanja otrokovega razvoja. Pričakujejo, da se bodo dojenčki odzvali s smehom in željo po interakciji. V tradicionalnih kulturnih okoljih matere glasbo izvajajo za umirjanje in uspavanje dojenčka. Zadovoljne so, če se dojenček ob petju umiri in zaspi (Toda 1990 v Sloboda 2007). Skupaj z Arnoldom Bentleyjem (1913-2001) sta pod vplivom teorije o splošnem inteligenčnem kvocientu računala kvocient muzikalnosti. Strokovnjaki ugotavljajo, da so prve glasbene izkušnje večine dojenčkov povezane s poslušanjem žive glasbe doma. Dom in starši so pomembni učitelji glasbe v kritičnem obdobju glasbenega razvoja do 18. meseca starosti (Gordon 1997). Neformalno glasbeno učenje ob petju in gibanju ob glasbi sta zadostna pogoja za otrokov nadaljnji glasbeni razvoj. Ob tem dobi še eno izkušnjo več - da sta življenje in umetnost medsebojno povezana (Gordon 1997).

Edwin Gordon je obdobje privajanja otroka na glasbo v okolju raziskoval z vidika razvoja avdiacije kot oblike glasbenega mišljenja. Prvo fazo razvoja, ki traja od rojstva do drugega oziroma četrtega leta starosti, poimenuje inkulturacija (angl. acculturation). $V$ tem obdobju otrok doseže tri razvojne stopnje: (1) vsrkavanje (angl. absorption) glasbe iz okolja, ki mu omogoča izgrajevanje poslušalskega besednjaka za nadaljnje izvajanje in ustvarjanje glasbe; (2) nenamerne (angl. random response) odzive na glasbo, tako imenovano glasbeno bebljanje in (3) namerne odzive na glasbeno izvajanje drugega (angl. purposeful response) (Bluestin 2000).

Najzgodnejša oblika namernega glasbenega vedênja je sposobnost dojenčka za posnemanje posameznih tonskih višin. Vendar pa ni dokazov, da 
bi dojenčki posnemali melodične vzorce, tudi če bi bili sestavljeni le iz dveh tonov (Schellenberg in Trebuh 1996; Kessen Levine in Wedrich 1979 v Sloboda 2007; Hargreaves 2001). Pogosteje prepoznamo drugo obliko glasbenega oz. govornega vedenja - vokalizo ali bebljanje. ${ }^{13}$ Glasbeno bebljanje opredeljujemo kot obliko ekspresivnega odziva dojenčka na glasbo in zvoke iz okolja, pa tudi kot težnjo po vzpostavljanju interakcij z okoljem (Hargreaves 2001). Tovrstne glasovne odzive dojenčka je prvi raziskoval Helmut Moog. Glasovne odzive v obliki tonskih gibanj navzdol na enem vokalu je opazil že pri nekaterih tri mesece starih dojenčkih, pogosteje pa pri šest in $v$ večini pri devet mesecev starih dojenčkih. Tovrstno predverbalno komunikacijo med starši in dojenčkom sta raziskovala tudi M. Papoušek in H. Papoušek. Ugotovila sta, da se med starši in dojenčki vzpostavi svojsko sporazumevanje kot neke vrste predjezikovni kod, ki vsebuje glasbene prvine, skupne govornemu in glasbenemu bebljanju, npr. višino in modulacijo glasu, glasnost, barvo glasu in poudarke. Pomembna je tudi ugotovitev, da pri tem starši uporabljajo tudi neverbalne oblike komunikacije, kot so dotik, gestikuliranje in izraz na obrazu. Integracija neverbalne komunikacije in glasbenega izvajanja je za dojenčka pomembna spodbuda za nadaljnje razvijanje sposobnosti zaznavanja (Papoušek 1996).

$\checkmark$ glasbenem bebljanju še ne prepoznamo zametkov glasbene sintakse, značilne za glasbo $v$ določenem kulturnem okolju. Zato pri dojenčku še ne moremo govoriti o imitaciji kot značilni obliki glasbenega vedênja, ki se običajno pojavi po 18. mesecu starosti (Gordon 1995). Kljub temu lahko dosežke glasbene akulturacije dojenčka strnemo v naslednje tri ugotovitve: (1) dojenček ob koncu 1. leta razlikuje glasbene in neglasbene zvoke, kar pokaže s posebno pozornostjo na zvok, z gibanjem in vokalizo; (2) izraža preference do glasbenih zvokov, še posebej do petja in instrumentalne glasbe; (3) posnema posamezne tonske višine; (4) zaznava ritmične in melodične spremembe $v$ zaporednih ponovitvah glasbenih vzorcev, če prej sliši večkratno ponovitev prvega glasbenega vzorca (Sloboda 2007).

Ugotavljamo, da rezultati raziskav potrjujejo pomen procesov inkulturacije $v$ družinskem okolju za glasbeni razvoj dojenčka, še posebej v povezavi s petjem matere oz. skrbnika.

\section{Sklepne ugotovitve}

Novejši pristopi k raziskovanju glasbenega razvoja v zgodnjem obdobju so razširili in poglobili razumevanje odzivov otroka na glasbene spodbude. Pre-

\footnotetext{
${ }^{13}$ Raziskovalci ločijo govorno in glasbeno bebljanje.
} 
lomnico predstavljajo raziskave o glasbeni zavesti dojenčka. Dojenček je zmožen zaznavati razmerja med tonskimi višinami in trajanji v zaporedno izvedenih melodičnih ter ritmičnih vzorcih. Sloboda (2007) te odzive opredeli kot prvo obliko glasbenega vedênja. Te sposobnosti dojenčka se povezujejo z njegovimi glasbenimi dispozicijami, odličnim spominom za glasbo, radovednostjo in bogatim glasbenim okoljem. Dojenček je lahko dober poznavalec glasbe, če je deležen raznovrstnih glasbenih izkušenj. Tako procesi akulturacije dobijo pomen $v$ družinskem okolju. Dosežki tovrstne socializacije otroka z glasbo se ob koncu prvega leta kažejo $v$ zmožnostih razlikovanja glasbenih in neglasbenih zvokov, izražanja preferenc do petja in instrumentalne glasbe, glasbenega bebljanja, posnemanja tonskih višin in zaznavanja sprememb v zaporedno izvedenih melodičnih ter ritmičnih vzorcih. Edwin Gordon je te procese preučeval z vidika razvoja avdiacije kot oblike glasbenega mišljenja; pri tem izpostavi potrebo po neposrednem stiku dojenčka z glasbo $v$ živo, še posebej petju. Ugotovitve so pomembna iztočnica za nadaljnje razvijanje pristopov k zgodnjemu učenju glasbe. Vzor nekateri strokovnjaki vidijo $v$ naravnem didaktičnem modelu verbalne, neverbalne in glasbene komunikacije matere $z$ dojenčkom. Intimen odnos med njima, ki se vzpostavi med izvajanjem glasbe $v$ živo, ima tudi močen doživljajski naboj.

\section{Literatura}

Bamberger, J. 2000. Developing Musical Intuitions: A Project-Based Introduction to Making and Understanding Music. Oxford: Oxford University Press.

Bluestine, E. 2000. The Ways Children Learn Music: An Introduction and Practical Guide to Music Learning Theory. Chicago: GIA Publications.

Borota, B. 2009. »Podoba velikega glasbenika skozi očala Reggio Emilia.« V Izzivi pedagoškega koncepta Reggio Emilia, ur. T. Devjak in D. Skubic, 135-150. Ljubljana: Pedagoška fakulteta.

- 2013. Glasbene dejavnosti in vsebine. Koper: Annales.

Chang, H. W., in S. E. Trebuh. 1997a. »Auditory Processing of Relational Information by Young Infants." Journal of Experimental Child Psychology 24:324331.

- 1997b. »Infants' Perception of Temporal Grouping in Auditory Patterns." Child Development 48 (4): 1666-1670.

Deliège, I. in Sloboda, J. 1996. Musical Beginnigs: Origins and development of Musical Competence. Oxford: Oxford University Press.

Gardner, H. 1995. Razsežnosti uma. Ljubljana: Tangram.

Gordon, E. E. 1967. »The Musical Aptitude Profile.« Music Educators Journal 53 (6): 52-54.

. 1984. Study Guide for Learnig Sequences in Music: Skill, Content, and Patterns. Chicago: GIA Publications. 
. 1986. The Nature, Description, Measurement and Evaluation of Music Aptitude. Chicago: GIA Publications.

—. 1995. »The Role of Music Aptitude in Early Childhood Music.« Early Childhood Conections 1 (1-2): 14-21.

_ 1997. A Music Learning Theory for Newborn and Young Children. Chicago: GIA Publications.

Hargreaves, D. J. 2001. The Developmental Psychology of Music. Cambridge: Cambridge University Press.

Kessen, W., J. Levine in K. Wendrick. 1979. »The Imitation of Pitch in Infants." Infant Behavior and Development 2:93-100.

Mayesky, M. 2009. Creative Activities for Young Children. Clifton Park, NY: Delmar Cengage Learning.

Moog, H. 1976. The Musical Experience of the Pre-School Child. London: Schott.

Motte-Haber, H. 1990. Psihologija glasbe. Ljubljana: Državna založba Slovenije.

Oblak, B. 2001. Glasbena slikanica 3: priročnik za učitelje. Ljubljana: DZS.

Papoušek, M. 1996. »Intuitive Parenting: A Hidden Source of Musical Stimulation in Infancy.« V Musical Beginnings: Origins and Development of Musical Competence, ur. I. Deliège in J. Sloboda, 88-114. Oxford: Oxford University Press.

Papoušek, M., H. Papoušek in D. Symmes. 1991. »The Meanings of Melodies in Motherese in Tone and Stress Languages."Infant Behavior and Development 14 (4): 415-440.

Radoš, K. 2010. Psihologija muzike. Beograd: Zavod za udžbenike.

Révész, G. 2001. Introduction to the Psychology of Music. Mineola, NY: Dover.

Rinaldi, C. 2006. In Dialogue with Reggio Emilia. London: Routledge.

Rojko, P. 1981. Testiranje u muzici. Zagreb: Muzikološki zavod Muzičke akademije u Zagrebu.

Schellenberg, E. G., in S. E. Trebuh. 1996. »Natural Musical Intervals: Evidence From Infant Listenars. Psychological Science 7 (5): 272-277.

Schubert, E., in G. E. McPherson. 2006. »The Perception of Emotion in Music. \V The Child as Musician, ur. G. McPherson, 193-212. Oxford: Oxford University Press.

Seashore, C. E. 1969. Psychology of Music. New York: Dover.

Shuter-Dyson, R., in C. Gabriel. 1981. The Psychology of Musical Ability. London: Methuen.

Sicherl-Kafol, B. 2001. Celostna glasbena vzgoja: srce, um, telo. Ljubljana: Debora. Sloboda, J. 2007. The Musical Mind. Oxford: Oxford University Press.

Smolej-Fritz, B. 2000. »Razvoj vidikov glasbenih sposobnosti, ki jih meri Bentleyev test. «Psihološka obzorja 9 (1): 91-106.

Toda, S., A. Fogel in M. Kawai. 1990. »Maternal Speech to Three-Month-Old Infants in the United States and Japan." Journal of Child Language 17:279294. 
Trebuh, S. E. 2006. »Infants as Musical Connoisseurs."V The Child as Musician, ur. G. McPherson, 33-50. Oxford: Oxford University Press.

Trebuh, S. E., in E. E. Hannon. 2006. »Infant Music Perception: Domain-General or Domain-Specific Mechanisms?« Cognition 100:7399.

Trebuh, S. E., in L. J. Trainor. 1998. "Singing to Infants: Lullabies and Play Songs." Advances in Infancy Research 12:43-77.

Trebuh, S. E., D. S. Hill in S. B. Kamenetsky. 1997. »Parents' Sung Performances for Infants." Canadian Journal of Experimental Psychology 51 (4): 385-396.

Zupančič, M. 2004. »Zaznavni in spoznavni razvoj dojenčka in malčka. "V Razvojna psihologija, ur. L. Marjanovič Umek in M. Zupančič, 186-214. Ljubljana: Filozofska fakulteta.

\section{Researching Musical Development and the Significance of Musical Environment for Babies}

Researching musical development in babies is a special challenge, which in the 2oth century was addressed in various ways. The look at the approaches to research from a diachronic perspective reveals a significant shift from observing one's own children and testing in laboratories to observing musical behaviour in natural environment. Under the influence of other sciences diverse responses of babies to music were interpreted as forms of musical behaviour rather than as response to a stimulus from the environment. Based on the knowledge of inborn musical dispositions the knowledge about the forms of musical behaviour changed. In the paper we therefore defend the assumption that babies are great connoisseurs of music. Here we emphasize the importance of the processes of acculturation in the family environment and redefine some of the forms of musical behaviour of babies in relation to their perceptual abilities and the development of musical awareness. Based on studies in American cultural environment we also conclude that in the first year of life the baby's responses to music and sounds cannot already be interpreted as forms of melodic or rhythmical behaviour or linked to the ability of imitating music.

Keywords: research of musical development, musical development of babies, musical dispositions, forms of musical awareness in babies 